\title{
The Impact of Capital Requirements on U.K. Bank Behaviour
}

Tolga Ediz, Ian M ichael, and William Perraudin

\section{CAPITAL REQUiREMENTSAND THEIR \\ POTENTIAL IMPACT ON BANK BEHAVIOUR}

The 1988 Basle Accord obliges banks to maintain equity and quasi-equity funding equal to a risk-weighted proportion of their asset base. Regulators' intentions in adopting the Accord were, first, to reinforce financial stability, second, to establish a level playing field for banks from different countries, and third, in the case of some countries, to reduce explicit or implicit costs of government-provided deposit guarantees. But extensive reliance by banking supervisors on capital requirements inevitably begs questions about the possibly distortionary impact on bank behaviour.

The most obvious possible, and undesirable, impact on bank behaviour of risk-weighted capital requirements is that excessive differentials in the weights applied to different categories of assets might induce banks to substitute away from highly risk-weighted assets. In the early 1990s, U.S. banks shifted sharply from corporate lending to investing in government securities, and many commen-

Tolga E diz is an economist and Ian M ichael a senior manager in the Regul atory Policy D ivision of the Bank of England. W illiam Perraudin is a professor of finance at $B$ irkbeck College, $U$ niversity of $L$ ondon, and special advisor to the R egulatory Policy D ivision of the B ank of England. tators and researchers have attributed this shift to the postBasle Accord system of capital requirements.

W hile papers such as $\mathrm{H}$ all (1993), H aubrich and Wachtel (1993), Calem and Rob (1996), and Thakor (1996) make a persuasive case that capital requirements played a role in this switch, the conclusion is not entirely uncontroversial. H ancock and W ilcox (1993), for example, present evidence that U.S. banks' own internal capital targets explain the decline in private sector lending better than do the capital requirements imposed by regulators. Furthermore, the fact that capital requirements affect bank behaviour does not of course imply that the impact is undesirable. Bank supervisors must judge whether the induced levels of capital are adequate, or not, given the broad goals of regulation.

A second potential, undesirable impact on banks of risk-weighted, capital requirements of the Basle Accordtype is that banks may shift within each asset category toward riskier assets. Imposing equal risk weights on different private sector loans may make the safer, lower yielding assets less attractive, leading to substitution toward higher risk investments. Kim and Santomero (1988) show formally how a bank that maximises mean-variance preferences and faces uniform proportional capital requirements may substitute toward higher risk assets. 
Theoretical contributions by K eeley and Furlong $(1989,1990)$ and Rochet (1992) show that such substitution effects are sensitive to assumptions about banks' objective functions and to whether or not asset markets are complete. The extent to which banks are affected by this kind of distortion therefore remains an empirical question. Several recent econometric studies have looked for substitution effects attributable to capital requirements using data on U.S. banks. See, for example, Shrieves and Dahl (1992), H aubrich and Wachtel (1993), and Jacques and Nigro (1997).

\section{CAPitAl REQuirements \\ IN THE UNITED KINGDOM}

All the empirical papers cited above draw on the U.S. experience. U.S. data have many advantages, most notably the very large number of banks for which data are available and the detailed information one may obtain on individual institutions. $\mathrm{N}$ evertheless, it is important to examine the impact of capital requirement systems operating in other countries. Although the Basle approach provides a basic framework of minimum capital standards, regulators in different countries have supplemented it with a range of other requirements that deserve empirical investigation. Furthermore, data from other (that is, non-U .S.) banking markets may shed interesting light on the effects of capital requirements simply because they constitute a largely independent sample. The impact of capital requirements can only really be studied by looking at cross-sectional information on banks. Since U.S. banks are inevitably subject to large common shocks, banking industries in other countries provide a val uable additional source of evidence.

In our paper titled "Bank Capital Requirements and Regulatory Policy" (1998), we employ confidential supervisory data for B ritish banks to address some of the issues outlined above. The panel data set we use comprises quarterly balance sheet and income data from ninety-four banks stretching from fourth-quarter 1989 to fourthquarter 1995. The two questions we are primarily interested in are (a) does pressure from supervisors affect bank capital dynamics when capital ratios approach their regulatory minimum, and (b) by adjusting which items in their balance sheets do banks increase their capital ratios when subject to regulatory pressure?

\section{Bank Capital Regulation \\ IN THE UNITED KINGDOM}

To understand the interest and implications of our study, it is important to have a clear idea of the operation of bank capital regulation in the U nited K ingdom. W hile the U .K. approach is fully consistent with the basic standards laid down in the Basle A ccord, various additional requirements are placed on banks by U .K. supervisors. First, U .K. supervisors set two capital requirements - a "trigger ratio," which is the minimum capital ratio with which a bank must comply, and a "target" ratio set somewhat above the trigger ratio. The gap between the target and the trigger acts as a buffer in that regulatory pressure is initiated when a bank's risk asset ratio (RAR) falls below the target. If the RAR falls below the trigger ratio, supervisors take more drastic action, and ultimately may revoke a bank's license.

A nother important feature of U.K. practice is that supervisors specify bank-specific capital requirements. Banks adjudged to be risky by the supervisors must meet higher capital requirements than less risky institutions. Risky in this context may reflect supervisors' evaluation of the bank's loan book or possibly their perception that there exist weaknesses in systems of control or in the competence of management. For most U.K. banks, capital require ments exceed the Basle minimum of 8 percent. The ability to vary a bank's capital requirement administratively provides regulators with a very useful lever with which they can influence the actions of the bank's management.

The empirical implications of the system described above are (a) that one might expect that banks experiencing or fearing regulatory pressure will seck to boost their capital ratios when their RARs enter a region above the regulatory minimum, and (b) that changes in a bank's trigger ratio will induce a change in the bank's capital dynamics. W e investigate these hypotheses bel ow.

\section{DATA DESCRIPTION}

Before looking at bank capital dynamics statistically, it is useful to examine our data to understand its basic 
structure. In Chart 1, we provide a scatter diagram of changes over a quarter in banks' RARs (pooled across banks and time periods) plotted against the lagged level of the RAR. Rather than expressing the lagged RAR in its natural units, we prefer to measure it in terms of deviations from the trigger ratio divided by the sample standard deviation of the RAR for each individual bank. This approach makes sense because banks are likely to change their behaviour, boosting their RARs, when they are in danger of hitting their regulatory minimum. The volatility of the RAR (which varies substantially across different banks) is just as important, therefore, as the actual distance in percent from the current RAR to the trigger.

To facilitate interpretation of Chart 1 , we include a simple OLS linear regression line of RAR changes on lagged RAR levels. As one might expect, this line is downward sloping, reflecting the fact that low initial RAR levels induce banks to rebuild their capital ratios. Perhaps the most interesting feature of the chart, however, is the fact that a clear nonlinearity is apparent in that deviations from the regression line for low levels of the RAR are consistently positive. This bears out our hypothesis that there exists a regime switch in bank capital dynamics in the region immediately above the trigger level.

The second question that interested us is exactly how banks go about increasing their capital ratios when they are low. Either banks might cut back private sector

Chart 1

Change in Risk Asset Ratio

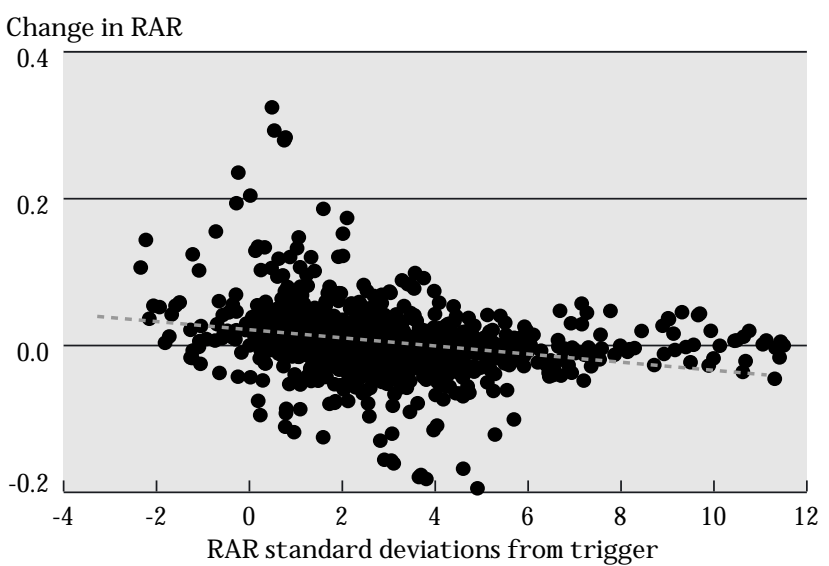

loans that bear high risk weighting in favour of government securities, for example, which attract low risk weights. Alternatively, banks might boost their capital directly by issuing new equity or by cutting dividends. As we noted in the introduction, the substitution by banks toward low-risk-weighted assets, which one might term the credit crunch hypothesis, has been thoroughly discussed in the case of U.S. banks in the early 1990s by a series of papers.

Chart 2 shows the change in 100-percentweighted assets as a ratio to total risk-weighted assets (TRWA ) plotted against the lagged level of the RAR. Once again, the RAR level is expressed as a deviation from the bank-specific trigger and is scaled by the standard devia tion of the RAR appropriate for each bank. The chart indicates that there exists only a slight positive relationship between changes in 100-percent-weighted assets and lagged RARs. Furthermore, the nonlinearity clearly evident in Chart 1 appears not to be present. Thus, banks only slightly reduce their holdings of 100-percent-weighted assets when their RARs fall close to trigger levels, and the credit crunch hypothesis appears not to be borne out.

Charts 3 and 4 repeat Chart 1 except for different capital ratios. Respectively, they show changes in Tier 1 and Tier 2 capital as ratios to total risk-weighted assets plotted against the lagged level of the RAR. Tier 1 repre sents narrow capital, mainly consisting of equity and

Chart 2

Change in 100-Percent -W eighted A sset s/TR W A

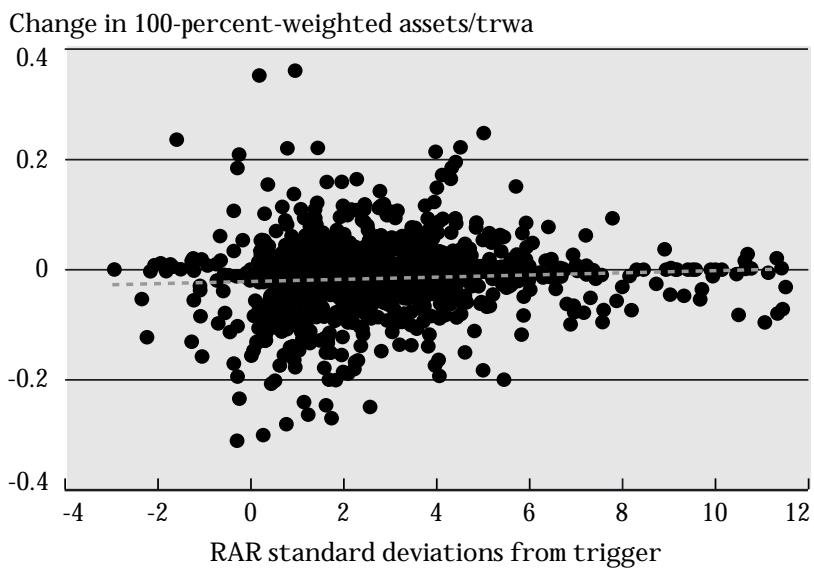


Change in Tier 1 Capital/TRW A

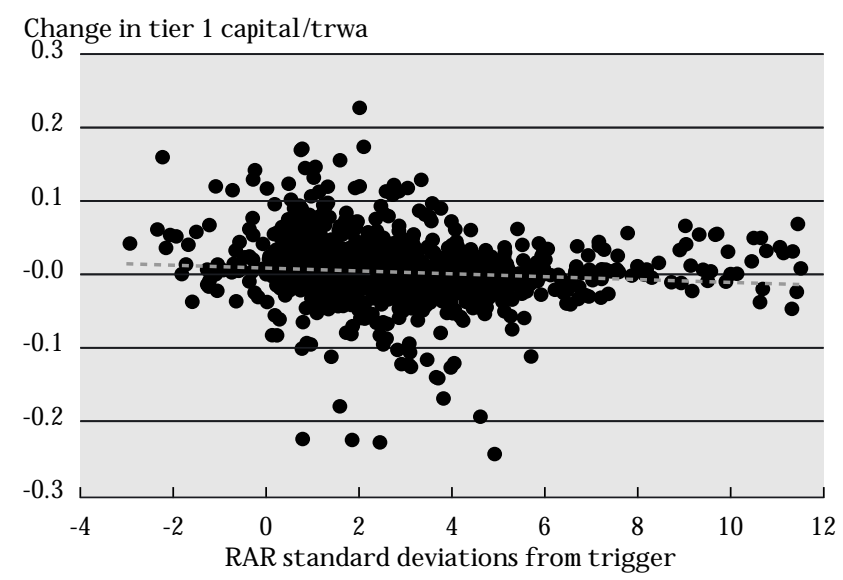

retained earnings. Recall that the Basle Accord specifies that banks have to hold a ratio of Tier 1 capital to risk-weighted assets of at least 4 percent. Tier 2 consists of broad capital less narrow capital and primarily comprises subordinated debt and other equity-like debt instruments. Both the Tier 1 and the Tier 2 scatter plots exhibit strong negative relationships between capital and the distance of the RAR from the trigger ratio.

\section{REGRESSION ANALYSIS}

Although scatter plots provide valuable clues to the bivariate relationship between capital changes and the lagged level of capital, a formal regression analysis must be

Chart 4

Change in Tier 2 Capit al/TR W A

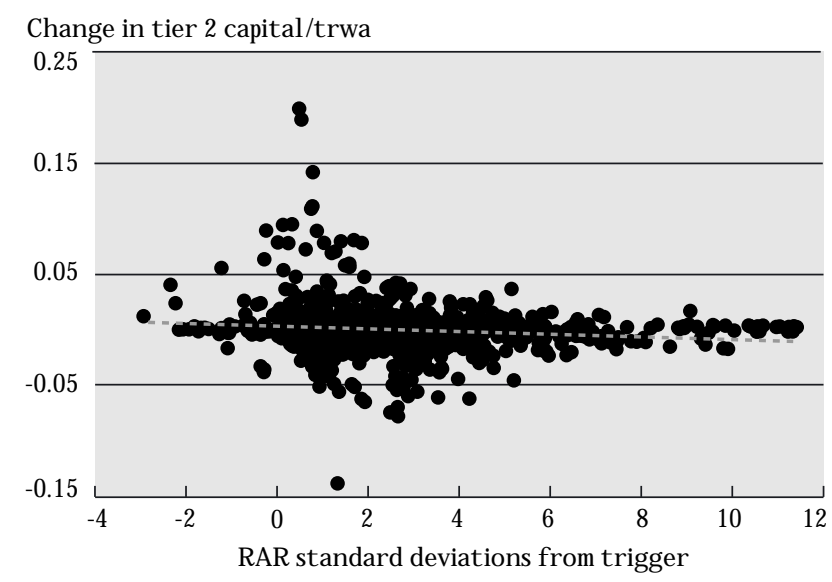

performed if one wishes to understand the impact on capital changes of regulatory pressure, holding other influences on capital constant. This is important because when a firm falls into financial distress, it may seek to adjust its capital in line with its own internally generated capital targets, even without intervention by regulators (see the discussion in $\mathrm{H}$ ancock and W ilcox [1993]). We, therefore, formulate a dynamic, multivariate panel regression model in which changes in capital ratios depend on the lagged level of the ratio, a range of conditioning variables describing the nature of the bank's business and its current financial health (these proxy for the bank's internal capital target), and variables that may be regarded as measuring regulatory pressure. Formally, our model may be stated as:

$$
Y_{n, t+1}-Y_{n, t}=\beta_{0}+\sum_{j=1}^{N} \beta_{j} X_{n, t, j}+\gamma Y_{n, t}+\varepsilon_{n, t} \text {, }
$$

where $E\left(\varepsilon_{n, t}\right)=E\left(X_{n, t, j} \varepsilon_{n, t}\right)=0$, t indicates the time period, and where $X_{n, t, j} j=1,2, \ldots . . N$ are a set of regressors.

$$
\varepsilon_{\mathrm{n}, \mathrm{t}+1}=\rho \varepsilon_{\mathrm{n}, \mathrm{t}}+v_{\mathrm{n}, \mathrm{t}} \quad \forall \mathrm{n}, \mathrm{t},
$$

where $E\left(v_{n, t}\right)=0$ for all $n, t$, and $E\left(v_{n, t} v_{m, s}\right)=0$ for all $t, s, n, m$ except when $t=s$ and $n=m$. To include random effects, we suppose that for any bank, $E\left(v_{n, t}^{2}\right)=\sigma_{n}^{2}$.

Our conditioning variables designed to proxy the bank's own internal capital target include net interest income over total risk-weighted assets, fee income over total risk-weighted assets, bank deposits over total deposits, total off-balance-sheet exposures over total risk-weighted assets, provisions over total risk-weighted assets, profits over total risk-weighted assets, and 100-percent-weighted assets over total risk-weighted assets. The net interest income, fee income, and 100-percent-weighted asset variables reflect the nature and riskiness of the bank's operations. Bank deposits and off-balance-sheet exposure variables reflect the bank's vulnerability to runs on deposits although they may al so reflect the degree of financial sophistication of the bank and its consequent ability to economise on capital. Total profit and loss and provisions variables indicate the bank's state of financial health.

We measure regulatory pressure in two ways. First, we incorporate a dummy variable that equals one if 
the bank has experienced an upward adjustment in its trigger ratio in the previous three quarters. Second, we include a dummy that equals unity if the RAR falls close to the regulatory minimum. As we argue above, the degree that a bank is "close" to its trigger depends not just on the absolute percentage difference between the current RAR and the trigger but also on the volatility of the RAR. Hence, we cal culate the dummy in such a way that it is unity if the RAR is less than one bank-specific standard deviation above the bank's trigger. Thus, our hypothesis is that there exists a zone above the trigger in which the bank's capital ratio choices are constrained by regul atory pressure. In this respect, our study is comparable to J acques and N igro (1997).

The dummy associated with a one-standarddeviation zone above the trigger may be regarded as introducing a simple regime switch in the model for low levels of the RAR. To generalise this regime switch, we also estimate switching regression models in which all the parameters on the conditioning variables (not just the intercept) are al lowed to change when the RAR is less than one standard deviation above the trigger. This specification al lows for the possibility that all the dynamics of the capital ratio change when the bank is close to its regulatory minimum level of capital.

In formulating our panel model, we adopt a random rather than a fixed-effects specification. We are not so interested in obtaining estimates conditional on the particular sample available that is the usual interpretation of the fixed-effect approach (see H siao [1986]) and so the random-effects approach seems more appropriate. Thus, we suppose that the variance of error terms has a bank-specific component. Furthermore, we suppose that the residual s are $A R(1)$. The latter assumption seems natural as one might expect shocks to register in bank capital ratios over more than a single quarter. The fact that error terms are autocorrelated somewhat complicates estimation since our model contains lagged endogenous variables. To avoid the biases in parameter estimates this would otherwise induce, we employ the instrumental variables approach introduced by $\mathrm{H}$ atanaka (1974).

Table 1 reports regression results for the case in which the dependent variable is the RAR. N ote that estimates in

\begin{tabular}{|c|c|c|c|c|c|c|}
\hline & \multicolumn{3}{|c|}{ RAR } & \multicolumn{3}{|c|}{ 100-Percent-W eighted Assets/TRWA } \\
\hline & & < trig + 1 s.d. & $>$ trig + 1 s.d. & & < trig + 1 s.d. & $>$ trig +1 s.d. \\
\hline & (1.38) & (1.63) & $(-0.73)$ & $(-0.28)$ & $(-2.21)$ & $(-3.17)$ \\
\hline \multirow[t]{2}{*}{ Change in trigger dummy } & 0.27 & 1.46 & - & -0.16 & -0.58 & - \\
\hline & $(1.42)$ & $(1.94)$ & - & $(-0.90)$ & $(-0.58)$ & - \\
\hline \multirow[t]{2}{*}{$\mathrm{N}$ et interest income/T RWA } & 0.04 & 4.57 & -0.66 & 1.30 & -8.95 & 1.72 \\
\hline & $(0.02)$ & $(0.41)$ & $(-0.23)$ & $(0.67)$ & $(-1.71)$ & $(0.83)$ \\
\hline \multirow[t]{2}{*}{ D eposits from banks/TRWA } & -0.19 & 0.54 & -0.30 & 0.14 & -0.12 & 0.32 \\
\hline & $(-1.82)$ & $(1.88)$ & $(-2.47)$ & $(1.47)$ & $(-0.87)$ & $(2.49)$ \\
\hline \multirow[t]{2}{*}{ (RAR trigger) less than 1 s.d. } & 0.44 & - & - & -0.03 & - & - \\
\hline & $(4.64)$ & - & - & $(-0.39)$ & - & - \\
\hline Total provisions/TRWA & $(1.26)$ & $(1.32)$ & $(0.70)$ & $(-0.54)$ & $(-0.27)$ & $(-0.16)$ \\
\hline \multirow[t]{2}{*}{ 100-percent-weighted assets/TRWA } & 0.19 & 0.31 & 0.05 & - & - & - \\
\hline & $(1.52)$ & $(1.05)$ & $(0.32)$ & - & - & - \\
\hline \multirow[t]{2}{*}{ Lagged dependent variable } & -0.44 & -2.62 & 0.77 & -0.08 & -1.64 & -0.06 \\
\hline & $(-0.81)$ & $(-0.92)$ & $(1.13)$ & $(-1.14)$ & $(-3.03)$ & $(-0.72)$ \\
\hline
\end{tabular}

N otes: TRWA and RAR denote total risk-weighted assets and risk/asset ratio. D ata are for ninety-four banks from fourth-quarter 1989 to fourth-quarter 1995 . Estimates are scal ed by 100. All regressions employ the $\mathrm{H}$ atanaka (1974) method. t-statistics appear in parentheses. 
the table are scal ed by 100. 0 ur estimates strongly suggest that capital requirements significantly affect banks' capital ratio decisions. The coefficient of the regime dummy is positive and significant. The point estimate implies that banks increase their RARs by around $1 / 2$ percent per quarter when their capital approaches the regulatory minimum. In addition, we find that banks raise their RAR by $1 / 3$ percent per quarter following an increase in their trigger ratio by the supervisors.

In columns 2 and 3 of Table 1, we report estimates for a switching regression model in which the coefficients on all the conditioning variables are allowed to change depending on whether the RAR is greater than or less than one standard deviation above the trigger. O ne might note that the impact of being near to or far from the trigger appears to change little between the simpler model and this generalised switching regression model. In the first case, the parameter estimate on the dummy for proximity to the trigger was $1 / 2$ percent, while the difference between the two intercepts in the switching regression model is al so around $1 / 2$ percent. By contrast, the magnitude of the dummy for recent increases in the trigger is far greater when we relax the specification, rising from $1 / 3$ percent in the simpler model to $11 / 2$ percent in the switching regression model.

One should also note that the coefficients on the conditioning variables in the regressions all have plausible signs. For example, higher profits reduce capital ratios while higher provisions or 100-percent-weighted assets increase them. It is al so interesting that in the switching regressions model, banks with greater reliance on bank deposits tend to increase their capital ratios. Overall, we conclude that capital requirements induce banks to increase their capital ratios even after one allows for internally generated capital targets. This conclusion is in contrast to that of $\mathrm{H}$ ancock and Wilcox (1993) in their study of U.S. banks.

The second question we are interested in is exactly how banks achieve changes in their capital ratios if they are subjected to regulatory pressure. The most obvious possibilities are either that they adjust the asset side of their balance sheets, for example, substituting government securities

Table 2

TIER 1 AND TIER 2 CAPITAL REgRESSION RESUltS

\begin{tabular}{|c|c|c|c|c|c|c|}
\hline & \multicolumn{3}{|c|}{ Tier 1 Capital/TRWA } & \multicolumn{3}{|c|}{ Tier 2 Capital/T RWA } \\
\hline & & $<$ trig + 1 s.d. & $>$ trig + 1 s.d. & & $<$ trig + 1 s.d. & $>$ trig + 1 s.d. \\
\hline Constant & $(1.95)$ & (3.03) & $(-2.64)$ & $(-3.40)$ & $(-3.63)$ & $(0.83)$ \\
\hline Change in trigger dummy & $(-0.69)$ & $(1.97)$ & - & $(0.74)$ & $(0.27)$ & - \\
\hline \multirow[t]{2}{*}{ Fee income/net interest income } & 0.00 & 0.02 & 0.00 & 0.00 & 0.01 & 0.00 \\
\hline & $(0.32)$ & $(0.41)$ & $(0.22)$ & $(0.63)$ & $(0.31)$ & $(0.38)$ \\
\hline \multirow[t]{2}{*}{ Deposits from banks/TRWA } & -0.15 & 0.40 & -0.19 & -0.03 & -0.00 & -0.03 \\
\hline & $(-1.52)$ & $(1.77)$ & $(-1.85)$ & $(-0.75)$ & $(-0.01)$ & $(-0.50)$ \\
\hline \multirow[t]{2}{*}{ (RAR trigger) less than 1 s.d. } & 0.17 & - & - & 0.15 & - & - \\
\hline & $(2.54)$ & - & - & (3.58) & - & - \\
\hline \multirow[t]{2}{*}{ Off-bal ance-sheet assets/TRW A } & 2.22 & -0.40 & 3.29 & 0.38 & 2.39 & 0.18 \\
\hline & $(2.04)$ & $(-0.14)$ & $(2.73)$ & $(1.04)$ & $(2.06)$ & $(0.28)$ \\
\hline 100-percent-weighted assets/TRW A & $(1.44)$ & $(-1.25)$ & $(2.52)$ & $(1.86)$ & $(1.75)$ & $(-1.61)$ \\
\hline \multirow[t]{2}{*}{ Lagged dependent variable } & 0.52 & -3.89 & 1.86 & -3.09 & -0.78 & -2.82 \\
\hline & $(1.13)$ & $(-1.83)$ & $(4.38)$ & $(-4.90)$ & $(-0.37)$ & $(-3.27)$ \\
\hline
\end{tabular}

N otes: TRW A and RAR denote total risk-weighted assets and risk/asset ratio. Data are for ninety-four banks from fourth-quarter 1989 to fourth-quarter 1995 . Estimates are scaled by 100. All regressions employ the $\mathrm{H}$ atanaka (1974) method. t-statistics appear in parentheses. 
(which attract low-risk weights in bank capital calculations) for private sector loans (which attract high-risk weights), or alternatively that they raise extra capital by issuing securities or by retaining earnings.

The three right-hand-columns of Table 1 show regressions of changes in 100-percent-weighted assets as a ratio to total risk-weighted assets on the lagged level of this ratio and on the same conditioning variables as those included in the $R A R$ regressions. Although the parameters for the two regulatory intervention dummies have the right signs, they are insignificant. The magnitudes of the point estimates are fairly small as well. In general, t-statistics are low, suggesting that the 100-percent-weighted asset ratio does not behave in a statistically stable way over time and across banks. In summary, it seems fair to conclude that banks do not significantly rely on asset substitution away from high-risk-weighted assets to meet their capital requirements as they approach the regulatory minimum.

Table 2 reports results for regressions similar to our RAR regressions reported above but using different capital ratios. Both the Tier 1 and Tier 2 capital ratio regressions we perform indicate that banks raise their ratios when they come close to their triggers. The response of banks to increases in their triggers is much higher for Tier 1 than for Tier 2 capital, suggesting that the bulk of the adjustment comes through increases in narrow capital. The adjustment in capital that occurs when banks are close to their triggers is more evenly spread across the two categories of capital.

\section{CONCLUSION}

In this paper, we summarise some of the results of Ediz, Michael, and Perraudin (1998) on the impact of bank capital requirements on the capital ratio choices of U.K. banks. We use confidential supervisory data including detailed information about the bal ance sheet and profit and loss of all British banks over the period 1989-95.

The conclusions we reach are reassuring in that capital requirements do seem to affect bank behaviour over and above the influence of the banks' own internally generated capital targets. Furthermore, banks appear to achieve adjustments in their capital ratios primarily by directly boosting their capital rather than through systematic substitution away from assets such as corporate loans, which attract high-risk weights in the calculation of Basle Accord-style capital requirements.

In short, this interpretation of the U.K. evidence makes capital requirements appear to be an attractive regulatory instrument since they serve to reinforce the stability of the banking system without apparently distorting banks' lending choices.

The views expressed in this article are those of the authors and do not necessarily reflect the position of the Federal Reserve Bank of New York or the Federal Reserve System. The Federal Reserve Bank of New York provides no warranty, express or implied, as to the accuracy, timeliness, completeness, merchantability, or fitness for any particular purpose of any information contained in documents produced and provided by the Federal Reserve Bank of New York in any form or manner whatsoever. 


\section{ENDNOTE}

The views expressed in this paper are theauthors' and do not necessarily refl ect the views of the B ank of England.

\section{REFEREN CES}

Calem, P.S., and R. R ob. 1996. "The Impact of Capital-Based Regulation on Bank Risk-Taking: A D ynamic M odel." Board of G overnors of the Federal R eserve System, Finance and Economics D iscussion Series 96, no. 12 (February): 36.

D ietrich, J. K., and C. J ames. 1983. "Regulation and the Determination of Bank Capital Changes." J OURN AL OF FIN AN CE 38, no. 5: 1651-8.

Ediz, T., I. M ichael, and W. R. M. Perraudin. 1998. "Bank Capital Dynamics and Regulatory Policy." Bank of England, mimeo.

H all, B. 1993. "H ow H as the Basle A ccord Affected Bank Portfolios?" J OURNAL OF THE JAPANESE AND INTERNATIONAL ECONOMIES 7: 408-40.

Hancock, D., and J. Wilcox. 1993. "Bank Capital and Portfolio Composition." Bank Structure and Competition. Federal Reserve Bank of Chicago.

H atanaka, M . 1974. "An Efficient Two-Step Estimator for the Dynamic Adjustment Model with Autoregressive Errors." JOURNAL OF ECONOMETRICS 2: 199-220.

H aubrich, J. G ., and P. W achtel. 1993. "Capital Requirements and Shifts in Commercial Bank Portfolios." Federal Reserve Bank of Cleveland ECONOMIC REVIEW 29 (third quarter): 2-15.

H siao, C. 1986. "Analysis of Panel Data." N ew York: Cambridge U niversity Press.
J acques, K. T., and P. N igro. 1997. "Risk-Based Capital, Portfolio R isk and Bank Capital : A Simultaneous Equations A pproach." J OU RN AL OF ECONOMICS AN D BUSINESS: 533-47.

K eley, M . C., and F . T . F urlong. 1989. "Capital Regulation and Bank Risk-Taking: A Note." JOURnAL OF BANKING AND FINANCE 13: 883-91.

- - - 1990. "A R eexamination of Mean-Variance A nalysis of Bank Capital Regulation." J OURNAL OF BANKING AND FIN ANCE 14: 69-84.

Kim, D., and A. Santomero. 1988. "Risk in Banking and Capital Regulation." J OURNAL OF FIN ANCE 43: 1219-33.

Roche, J. C. 1992. "Capital Requirements and the Behaviour of Commercial Banks." European Econ omic Review 36: 1137-78.

Shrieves, R. E., and D. D ahl. 1992. "The Relationship Between Risk and Capital in Commercial Banks." J OURn AL OF BANKIN G AND FIN AN CE 16: 439-57.

Thakor, A. V. 1996. "Capital Requirements, Monetary Policy, and A ggregate Bank Lending: Theory and Empirical Evidence." J OURNAL OF FINANCE 51, no. 1: 279-324. 